\title{
The Economic Comparison of Reservoir Type and Run of the River Type Hydropower Plants: A Case Study for Upper Kotmale Hydropower Plant
}

\author{
H.A.H. Amanda, W.A.D.S. Wijayapala, J.R. Lucas and W.J.L.S. Fernando
}

\begin{abstract}
Due to the severity of impacts predicted due to climate change issues, Greenhouse Gas (GHG) emissions need to be considered as a factor even for hydropower because of the identified emission possibilities associated with large reservoirs. Thus, when planning a large hydropower project at a selected location, it is important to decide on the type of power plant based on an economic comparison including environmental considerations. The existing 150MW, Talawakele run of the river type hydropower plant and the previously planned reservoir type Caledonia hydropower plant were selected for comparison in this study. Net greenhouse gas emissions from both projects were estimated based on several estimating techniques and for the economic comparison, the levelized cost of electricity of both projects were calculated. Results show that the unit cost of electricity generation from run of the river type is substantially lower (around LKR 4 per $\mathrm{kWh}$ ) than that of reservoir type. On the other hand, as Upper Kotmale is a peak-serving plant, a separate comparison was done considering the night peak operation. Results show a loss to the country (around LKR 2 billion per year) by energy reduction due to not implementing the reservoir type Caledonia hydropower plant. It is concluded that for future large hydropower developments in the world, a similar study should be carried out before deciding to downsize the reservoir. The study has further concluded that GHG emission considerations are not strong enough to discourage reservoir type new hydropower plant developments.
\end{abstract}

Keywords: Reservoir, run of river, hydropower, GHG emissions, levelized cost

\section{Introduction}

When planning a large hydropower project at a selected location, it is important to decide whether to construct a reservoir type or Run of the River (ROR) type based on an economic comparison including environmental and other considerations. There are environmental, social and economic impacts of hydropower projects which cannot be neglected, especially for large hydropower plants.

Owing to the severity of impacts predicted to be caused by climate change, GHG emissions need to be considered even for hydropower because of $\mathrm{CO}_{2}$ and $\mathrm{CH}_{4}$ emissions associated with large reservoirs. Disturbance to the ecosystem or loss of ecosystem is a negative impact to the environment including deforestation, impacts on fish owing to flow reduction and aesthetic effects on waterfalls. Reduced flow across waterfalls may cause reductions in tourism. Resettlement is a critical social impact caused by large hydropower projects. The economic advantage of reservoir type is the ability to store water and hence to be dispatched during both wet and dry seasons. Dry seasons affect the river flow of ROR type and hence the electricity generation.
The objectives of this research are to estimate the quantifiable advantages and disadvantages of reservoir type and ROR type hydropower generation, and to assess the economic impacts of converting reservoir type hydropower projects to ROR type hydropower projects at the design stage. In addition to costs related to power plants, costs related to environmental, social and economic impacts of hydropower are considered for project comparison.

Almost all the major hydropower potential has been developed in Sri Lanka by now. Out of the two existing large ROR type hydropower plants, Upper Kotmale Hydropower Project (UKHP) was taken as the case study for this

Eng. H.A.H. Amanda, BSc Eng (Hons) (Moratuwa), MSc (Moratuwa), AMIE(SL), AM(SLEMA), Electrical Engineer, Lanka Energy Conservation (Pvt) Ltd.

Eng. W.D.A.S. Wijayapala, BSc Eng (Hons) (Moratuwa), MEng(Moratuwa), Int.PEng(SL), CEng, FIE(SL), Senior Lecturer, Department of Electrical Engineering, University of Moratuwa.

Eng. (Prof.) J.R. Lucas, BSc Eng (Hons) (Cey), MSc (Manch), PhD (Manch), FIEE, CEng, FIE(SL), MCS(SL), Emeritus Professor, Department of Electrical Engineering, University of Moratuwa.

Eng. W.J.L.S. Fernando, BSc Eng (Hons) (Moratuwa), MEng (Bangkok), CEng, FIESL, MIET (UK), ChairmanNational Engineering Research and Development Centre. 
research. However, as there are other countries with untapped potential of hydropower, this research outcomes will especially be important to them.

\section{Literature Review}

Worldwide research publications on comparison between reservoir type and ROR type hydropower plants were studied to identify the research gap.

A study [1] has been conducted focusing on the Amazonian regions of Bolivia, Brazil, Colombia, Ecuador and Peru, where a large untapped hydropower potential is available, qualitatively comparing the reservoir type and ROR type based on the climate change impacts. The study concludes that it will be necessary to invest in reservoirs to increase the margin of reserve and cope with climate change. The study also indicates the local, social and environmental impacts associated with the exploitation of hydropower. Another study [2] has also been conducted based on the climate change impacts of hydropower, focusing on Central and South American regions where $60 \%$ of the electricity demand is met through hydropower. Building new storage reservoirs is given in it as a potential adaptation measure.

A review [3] done for Yunnan in China, qualitatively compares small and large hydropower projects for their environmental implications and socio-economic consequences. A comparison [4] between large and small hydropower projects in Tibet, based on the $\mathrm{CO}_{2}$ equivalent states that small hydro performs better in terms of environmentally friendly development and low carbon energy than large hydro. In Tibet, large hydropower plants are essential to meet the large and growing electricity demand.

A study [5] from Western Himalayan region of India on environmental sustainability of ROR hydropower projects has been conducted. It presents a public perception cum data collection study on environmental impacts of small and large ROR hydropower projects. It concludes that every environmental impact of small hydropower is not "small" as compared to large hydropower and ignoring environmental impacts of small hydropower may not be a good practice in the Himalayan region.

A case study [6] has been conducted for Uma Oya hydropower project in Sri Lanka incorporating economic and socio- environmental considerations into project assessment but GHG emissions from reservoir has not been considered in that.

Findings in the last two decades indicate that hydropower reservoirs produce GHGs as $\mathrm{CO}_{2}$ and $\mathrm{CH}_{4}$, raising the question whether hydro power based generation is a clean and green electricity source [7],[8]. Most of the past world studies [9],[10],[11],[12],[13] focused on GHG emissions from hydropower reservoirs due to flooded organic matter decaying under water and the quantifications were based on long term field measurements. The results were summarized for tropical and non-tropical regions separately.

Latest research findings on methods of GHG emissions from hydropower and quantification of them were studied because it is an emerging study area at present. The study done by A.B. Hidrovo et al., "Accounting for GHG net reservoir emissions of hydropower in Ecuador"[8], presents a rough and holistic estimate of net annual GHG emissions from reservoirs in the absence of long term field measurements. It is difficult to estimate the costs related to all ecological impacts of hydropower projects and their research covered only deforestation.

\section{Case Study}

There are many reservoir type large hydropower projects in Sri Lanka [14] but only two large ROR type projects, namely Upper Kotmale Hydropower Project (UKHP) (150MW) and Kukule Ganga Hydropower Project $(70 \mathrm{MW})$ are in operation at present. These two were constructed during the recent past, compared to the time period in which the other reservoir type projects were implemented in Sri Lanka. Out of the above two, UKHP was selected for the case study in this research.

For UKHP, an earlier planned (1985-1987) Caledonia reservoir type project and the already implemented Talawakele ROR type project are taken for comparison. These two sites are located at Kotmale Oya in Nuwara Eliya District, Central Province, Sri Lanka. The distance between the two locations is about $10 \mathrm{~km}$. Table 1 gives the salient features of these two projects. The estimated cost of Caledonia reservoir project is given in 1986 prices. This price to be adjusted to 2014 prices for the economic comparison under this study and adjusted project cost is shown in Table 11. 
Table 1 - Project features

\begin{tabular}{|l|r|r|}
\hline \multicolumn{1}{|c|}{ Item } & $\begin{array}{r}\text { Caledonia } \\
\text { Reservoir } \\
{[\mathbf{1 5}]}\end{array}$ & $\begin{array}{c}\text { Talawakele } \\
\text { ROR }\end{array}$ \\
\hline Catchment $\left(\mathrm{km}^{2}\right)$ & 235.80 & 310.60 \\
\hline Dam type & $\begin{array}{r}\text { concrete } \\
\text { gravity }\end{array}$ & $\begin{array}{r}\text { concrete } \\
\text { gravity }\end{array}$ \\
\hline Dam height (m) & 70.00 & 34.00 \\
\hline $\begin{array}{l}\text { Gross storage } \\
\text { capacity (MCM) }\end{array}$ & 45.10 & 2.50 \\
\hline $\begin{array}{l}\text { Effective storage } \\
\text { capacity (MCM) }\end{array}$ & 30.00 & 0.80 \\
\hline $\begin{array}{l}\text { Reservoir/pond } \\
\left.\text { Area (km }{ }^{2}\right)\end{array}$ & 2.25 \\
\hline Rated head (m) & 614.00 & 473.00 \\
\hline $\begin{array}{l}\text { Maximum turbine } \\
\text { discharge (m } / \mathrm{s})\end{array}$ & 40.00 & 36.90 \\
\hline $\begin{array}{l}\text { Installed capacity } \\
\text { (MW) }\end{array}$ & 214.00 & 150.00 \\
\hline $\begin{array}{l}\text { Estimated Annual } \\
\text { Energy (GWh) }\end{array}$ & 664.00 & 409.00 \\
\hline $\begin{array}{l}\text { Project cost } \\
\text { (million LKR) }\end{array}$ & $1986)$ & $\begin{array}{r}53,040 \\
\text { (base year } \\
2014)\end{array}$ \\
\hline
\end{tabular}

The original proposal of Talawakele ROR had suggested to take tributary diversions to the main stream (Kotmale Oya) in order to get a larger catchment area. Accordingly, the annual energy generation was originally estimated as 512.00 GWh in the Environmental Study in 1995, but five waterfalls were to be impacted due to that proposal. Therefore, all the tributary diversions were cancelled. That resulted in the reduction of the annual energy to $409.00 \mathrm{GWh}$ in the implemented Talawakele ROR project.

\section{GHG Emissions from}

\section{Hydropower Projects}

In reservoirs/ponds, there are decomposed organic matter (flooded and upstream organic matter). These organic matters produce $\mathrm{CO}_{2}$ and $\mathrm{CH}_{4}$ which reach the water surface layer and release to the atmosphere by diffusion. $\mathrm{CH}_{4}$ is also released by bubbling. These bubbles are produced in the methanogenesis process. Less $\mathrm{CO}_{2}$ bubbles are also produced because $\mathrm{CO}_{2}$ has a higher solubility than $\mathrm{CH}_{4}$. GHG are again released to the atmosphere by degasification when the water passes through the spillways of the dam and turbines. This is due to the change of temperature, pressure and turbulence. GHG are also released to the atmosphere by diffusion in the downstream river. The previously generated turbulence helps the gases to be easily diffused to the air.
These emissions can be precisely determined by long term field measurements. In the absence of long term field measurements, a complete, rough and holistic estimate of net GHG emissions from hydropower projects per year $\left(E_{n}\right)$ can be obtained from the Equation 1[8].

$$
E_{n}=E_{e}+E_{r}+E_{t s d}+E_{c o m}
$$

Where,

$\mathrm{E}_{\mathrm{e}} \quad$ = GHG emissions due to the loss of ecosystem (pre-flooding)

$\mathrm{E}_{\mathrm{r}} \quad=\mathrm{GHG}$ emissions from reservoir

$\mathrm{E}_{\mathrm{tsd}}=\mathrm{GHG}$ emissions from turbine, spillway and downstream river (postflooding)

$\mathrm{E}_{\mathrm{com}}=\mathrm{GHG}$ emissions from construction, operation and maintenance

\subsection{Estimation of Emissions from Loss of} Ecosystem

The formula of photosynthesis and respiration [8], [16] was applied to estimate $E_{e}$. This is given in Equation 2.

$$
\begin{array}{rl}
\mathrm{CO}_{2}(264 g)+\mathrm{H}_{2} & \mathrm{O} \\
& \rightarrow 108 \mathrm{~g}) \\
& \left.\rightarrow \mathrm{C}_{6} \mathrm{H}_{12}\right) \mathrm{O}_{6}(180 \mathrm{~g})+\mathrm{O}(192 \mathrm{~g}) \\
& \rightarrow \text { Amylase }(162 \mathrm{~g})
\end{array}
$$

The particular element called amylase is related to growth of dry matter in a plant. Dry matter weight of a plant type can be obtained from its Net Primary Production (NPP) data [8]. Table 2 gives typical NPP values for tropical forest and cultivated land [17].

Table 2 - NPP values

\begin{tabular}{|l|r|}
\hline \multicolumn{1}{|c|}{ Land Type } & \multicolumn{1}{|c|}{ NPP } \\
& (dry matter $\mathbf{( g )} / \mathbf{m}^{2} /$ year) \\
\hline Tropical forest & $1,500.00$ \\
\hline Cultivated land & 650.00 \\
\hline
\end{tabular}

Table 3 gives the land use prior to inundation for the two selected projects.

Table 3 - Land use of the selected projects

\begin{tabular}{|l|r|r|r|r|}
\hline \multirow{2}{*}{ Land Use } & \multicolumn{2}{|c|}{$\begin{array}{c}\text { Caledonia } \\
\text { Reservoir }\end{array}$} & \multicolumn{2}{c|}{$\begin{array}{c}\text { Talawakele } \\
\text { ROR }\end{array}$} \\
\cline { 2 - 5 } & $\begin{array}{r}\text { Land } \\
\text { Type }\end{array}$ & $\begin{array}{r}\text { Area } \\
\text { (ha) }\end{array}$ & $\begin{array}{r}\text { Land } \\
\text { Type }\end{array}$ & $\begin{array}{r}\text { Area } \\
\text { (ha) }\end{array}$ \\
\hline $\begin{array}{l}\text { Dam site and } \\
\text { reservoir }\end{array}$ & Tea & 232.00 & Tea & 33.80 \\
\hline $\begin{array}{l}\text { Resettlement } \\
\text { area }\end{array}$ & Tea & 368.00 & Tea & 26.20 \\
\hline $\begin{array}{l}\text { Power house } \\
\text { and } \\
\text { switchyard }\end{array}$ & Tea & 15.00 & Forest & 14.20 \\
\hline
\end{tabular}

Based on the information in Table 2 and Table 3 , the loss of dry matter production, and hence the $\mathrm{CO}_{2}$ emissions per year of the two sites are 
estimated as follows. NPP of tea plantations was assumed to be that of the available cultivated land data in literature.

- Loss of dry matter production due to loss of tea plantations in Caledonia reservoir project $=650 \mathrm{gm}^{-2} \mathrm{yr}^{-1} \times(232+368+15) \times 10^{4} \mathrm{~m}^{2}$ $=3,997.50$ ton $/$ year

Hence, $\mathrm{E}_{\mathrm{e}}=1.63 \times 3,997.50$ ton $\mathrm{CO}_{2} /$ year $=6,515.93$ ton $\mathrm{CO}_{2} /$ year

- Loss of dry matter production due to loss of tea plantations and forest in Talawakele ROR project

$$
\begin{aligned}
= & 650 \mathrm{gm}^{-2} \mathrm{yr}^{1} \times(33.80+26.20) \times 10^{4} \mathrm{~m}^{2+} \\
& 1500 \mathrm{~g} \mathrm{~m}^{-2} \mathrm{yr}^{-1 \times}(14.20) \times 10^{4} \mathrm{~m}^{2} \\
= & 603.00 \mathrm{ton} / \text { year }
\end{aligned}
$$

$$
\text { Hence, } \mathrm{E}_{\mathrm{e}}=1.63 \times 603 \text { ton } \mathrm{CO}_{2} / \text { year }
$$$$
=982.89 \text { ton } \mathrm{CO}_{2} / \text { year }
$$

\subsection{Estimation of Emissions from Reservoir}

When land is inundated, decaying organic matter under water results in GHG emissions. This GHG emission was estimated using Equation 3 [8],[18].

$$
E_{r}=E_{f} \times A_{e}
$$

Where,

$$
\begin{array}{ll}
\mathrm{E}_{\mathrm{f}} & =\text { Mean reservoir emission factor } \\
\mathrm{A}_{\mathrm{e}} & =\text { Area of reservoir/pond }
\end{array}
$$

Following long term field measurements data, past studies [8],[19],[20] have shown that reservoir GHG emissions decay exponentially against reservoir life.

According to Zhang et al [18], it is almost impossible to determine this reservoir GHG emissions precisely in the absence of long term field measurements. Therefore, Zhang et al has applied directly a constant mean reservoir emission factor for the total reservoir lifetime. It showed that, boreal regions have a significantly lower GHG emissions than tropical regions. The boreal region is defined as the zone having a definite winter with snow, and a short summer, generally hot [21].

Sri Lanka is a tropical country. Long term field measurements has not been done in Sri Lanka yet. Therefore, constant mean $\mathrm{E}_{\mathrm{f}}$ of tropical regions was selected for this research for the total power plant lifetime as given in Equation 3.
Tropical $\mathrm{E}_{\mathrm{f}}=2,771.60 \mathrm{~g} \mathrm{CO}_{2} \mathrm{eq} \mathrm{m}^{-2} \mathrm{yr}^{-1}$ [18]

Table 4 - Reservoir/Pond areas

\begin{tabular}{|l|r|}
\hline \multicolumn{1}{|c|}{ Reservoir/Pond } & Area $\mathbf{( k m}^{2} \mathbf{)}$ \\
\hline Caledonia reservoir & 2.25 \\
\hline Talawakele pond & 0.25 \\
\hline
\end{tabular}

GHG emissions from reservoir/pond are estimated as follows based on Equation 3.

- $\mathrm{E}_{\mathrm{r}}$ from Caledonia reservoir

$=2,771.60 \mathrm{~g} \mathrm{CO}_{2}$-eq $\mathrm{m}^{-2} \mathrm{yr}^{-1} \times 2.25 \times 10^{6} \mathrm{~m}^{2}$

$=6,236.10$ ton $\mathrm{CO}_{2}$-eq/year

- $\quad \mathrm{E}_{\mathrm{r}}$ from Talawakele pond

$=2,771.60 \mathrm{~g} \mathrm{CO}_{2}$ eq m $\mathrm{m}^{-2} \mathrm{yr}^{-1} \times 0.25 \times 10^{6} \mathrm{~m}^{2}$

$=692.90$ ton $\mathrm{CO}_{2}$-eq/year

It should be noted that there may be differences between reservoir and ROR pond water behaviour. Water is always stored in the reservoir but in Talwakele pond, water is collected during the day time and used during the night peak hours. This may affect reservoir/pond GHG emission patterns, which have not been considered here.

4.3 Estimation of Emissions from Turbine, Spillway \& Downstream River

According to Hidrovo et al [8], out of the total direct GHG emissions ( $E_{\mathrm{r}}$ and $\mathrm{E}_{\mathrm{tsd}}$ ), 45\% would come from the reservoir and 55\% would come from turbine, spillway and downstream. Therefore, $\mathrm{E}_{\text {tsd }}$ was determined by Equation 4 [8].

$$
E_{t s d}=\frac{E_{r} \times 55}{45}
$$

- $\quad E_{\text {tsd }}$ from Caledonia project $=7,621.90$ ton $\mathrm{CO}_{2 \text {-eq/year }}$

- $\quad E_{\text {tsd }}$ from Talawakele ROR project $=846.88$ ton $\mathrm{CO}_{2}$-eq/year

\subsection{Estimation of Emissions from Construction, Operation \& Maintenance}

Life Cycle Impact Assessment (LCIA) is an accepted tool which allows to identify the potential environmental impacts associated with a product or service, throughout its entire lifespan [22]. A LCIA has been performed by Hidrovo et al [22] to determine $\mathrm{E}_{\mathrm{com}}$.

For this research, LCIAs performed for reservoir type and ROR type hydropower projects were studied from literature. $E_{c o m}$ 
values of the two case study projects were estimated accordingly.

\subsection{1 $E_{\text {com }}$ of Caledonia reservoir project}

Turconi et al [22] have critically reviewed case studies involving LCA of electricity generation from hydropower and found that $\mathrm{E}_{\mathrm{com}}$ was in the value range of $11-20 \mathrm{~kg} \mathrm{CO}$-eq/MWh for dam reservoirs. Zhang et al [23] used LCA to compare two reservoir hydropower schemes, one with a concrete gravity dam (CGD) and the other with an earth-core rockfill dam (ECRD). They have found that the CGD scheme had a higher $\mathrm{E}_{\mathrm{com}} \quad\left(11.11 \quad \mathrm{kgCO}_{2}\right.$-eq/MWh) than ECRD.

Caledonia reservoir also has a CGD and hence the best available approximation of $\mathrm{E}_{\mathrm{com}}$ for Caledonia was made as $11.00 \mathrm{kgCO}_{2}$-eq/ MWh.

Total $\mathrm{E}_{\mathrm{com}}=\left(11 \mathrm{kgCO}_{2}-\mathrm{eq} / \mathrm{MWh}\right) \times 664 \times 10^{3} \mathrm{MWh}$

$$
=7,304.00 \text { ton } \mathrm{CO}_{2} \text {-eq } / \text { year }
$$

\subsection{2 $\quad E_{\text {com }}$ of Talawakele ROR project}

H. Hondo [24] performed LCIA for ROR type hydropower projects and found that a ROR (plant life: 30 years, plant factor: $45 \%$ ) with small reservoir had $\mathrm{E}_{\mathrm{com}}$ value as $11.00 \mathrm{kgCO}_{2^{-}}$ eq/MWh. The variation of that with plant life and plant factor is given in Table 5 and Table 6 [24].

Table 5 - Effects of lifetimes on $\mathrm{E}_{\mathrm{com}}$

\begin{tabular}{|l|c|c|c|c|c|}
\hline $\begin{array}{l}\text { Lifetime } \\
\text { (years) }\end{array}$ & $\mathbf{1 0}$ & $\mathbf{2 0}$ & $\begin{array}{c}\mathbf{3 0} \\
\text { (ref) }\end{array}$ & $\mathbf{5 0}$ & $\mathbf{1 0 0}$ \\
\hline $\begin{array}{l}\mathrm{E}_{\mathrm{com}} \\
\left(\mathrm{kgCO} 2^{-}\right. \\
\text {eq/MWh } / \mathrm{MWh}^{-}\end{array}$ & 30.00 & 16.00 & 11.00 & 8.00 & 5.00 \\
\hline
\end{tabular}

Talawakele ROR has a plant life of 50 years. Therefore, $\mathrm{E}_{\mathrm{com}}$ value was approximated as 8.00 $\mathrm{kgCO}_{2}$-eq/MWh which was a reduction by 3.00 $\mathrm{kgCO}_{2}$-eq/MWh than the reference.

Table 6 - Effects of plant factors on $E_{c o m}$

\begin{tabular}{|l|c|c|c|c|c|}
\hline $\begin{array}{l}\text { Plant } \\
\text { factors (\%) }\end{array}$ & $\begin{array}{c}\mathbf{- 1 0} \\
\text { pts }\end{array}$ & $\begin{array}{c}\mathbf{- 5} \\
\text { pts }\end{array}$ & $\begin{array}{c}\mathbf{4 5} \\
\text { (ref) }\end{array}$ & $\begin{array}{c}+\mathbf{+ 5} \\
\text { pts }\end{array}$ & $\begin{array}{c}\mathbf{+ 1 0} \\
\text { pts }\end{array}$ \\
\hline $\begin{array}{l}\mathrm{kgCO}_{2^{-}} \\
\text {eq/ } \mathrm{MWh}\end{array}$ & 14.00 & 13.00 & 11.00 & 10.00 & 9.00 \\
\hline
\end{tabular}

Talawakele ROR has a plant factor of $30 \%$ and hence the values in Table 6 were plotted, as shown in Figure 1, to obtain $\mathrm{E}_{\mathrm{com}}$ at that plant factor.

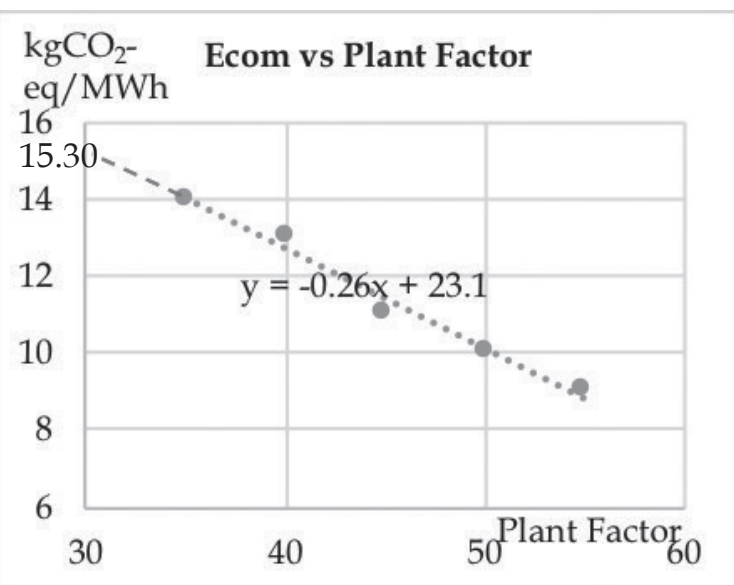

Figure 1 - Variation of $\mathrm{E}_{\text {com }}$ with plant factor in a ROR scheme with small reservoir

Extrapolation from Figure 1, gives the $E_{\text {com }}$ value for Talawakele $\mathrm{ROR}$ as $15.30 \mathrm{kgCO}_{2-}$ eq/ $\mathrm{MWh}$, which is an increase of $\mathrm{E}_{\text {com }}$ by 4.30 $\mathrm{kgCO}_{2}$-eq/MWh from the reference.

Based on these findings, the best available approximation of $\mathrm{E}_{\mathrm{com}}$ for Talawakele ROR project was made as $12.30 \mathrm{kgCO}_{2}$-eq/MWh, with 50 year plant life and 30\% plant factor.

$$
\begin{aligned}
\text { Total } \mathrm{E}_{\mathrm{com}}=\left(12.30 \mathrm{kgCO}_{2} \text {-eq } / \mathrm{MWh}\right) \times \\
\quad 409 \times 10^{3} \mathrm{MWh} \\
=5,030.70 \text { ton } \mathrm{CO}_{2} \text {-eq } / \text { year }
\end{aligned}
$$

\subsection{Total Emissions}

The net GHG emissions per year $E_{n}$ of Caledonia reservoir project and Talawakele ROR project were calculated and tabulated as in Table 7.

Table 7 - Net GHG emissions $\left(E_{n}\right)$ per year

\begin{tabular}{|l|c|r|}
\hline Parameter & $\begin{array}{c}\text { Caledonia } \\
\text { Project } \\
\text { (ton } \mathrm{CO}_{2-} \\
\text { eq/year) }\end{array}$ & $\begin{array}{c}\text { Talawakele } \\
\text { Project } \\
\text { (ton } \text { CO }_{2-} \\
\text { eq/year) }\end{array}$ \\
\hline $\mathrm{E}_{\mathrm{e}}$ & $6,515.93$ & 982.89 \\
\hline $\mathrm{E}_{\mathrm{r}}$ & $6,236.10$ & 692.90 \\
\hline $\mathrm{E}_{\mathrm{tsd}}$ & $7,621.90$ & 846.88 \\
\hline $\mathrm{E}_{\mathrm{com}}$ & $7,304.00$ & $5,030.70$ \\
\hline $\mathrm{E}_{\mathrm{n}}$ & $27,677.93$ & $7,553.37$ \\
\hline
\end{tabular}

The specific GHG emissions have also been calculated and tabulated in Table 8.

Table 8 - Specific GHG emission

\begin{tabular}{|l|c|c|c|}
\hline Project & $\begin{array}{c}\text { GWh/ } \\
\text { year }\end{array}$ & $\begin{array}{c}\text { Total } \\
\text { GHG } \\
\text { Emission } \\
\text { (ton CO } \\
\text { eq) } / \text { year }\end{array}$ & $\begin{array}{c}\text { Specific } \\
\text { GHG } \\
\text { Emission } \\
\text { (g CO }_{2-\text {-eq }} \\
/ \mathbf{k W h})\end{array}$ \\
\hline Caledonia & 664.00 & $27,677.93$ & 41.68 \\
\hline Talawakele & 409.00 & $7,553.37$ & 18.47 \\
\hline
\end{tabular}


It can be seen that even the GHG emissions from reservoir type hydropower projects are negligible compared to that of thermal power projects where specific GHG emissions are several hundred grams per kWh.

\section{Economic Comparison of Selected Hydropower Projects}

When making a decision on selecting a project among several project alternatives, technical feasibility and economic viability are two important criteria to be considered in engineering projects. The technical feasibilities of the two selected projects for comparison were ensured from their feasibility study reports. The decision making has been based on their economic viability.

\subsection{Levelized Cost of Electricity (LCOE)}

The economic comparison between the two types of plants was carried out by determining LCOE for each case.

$$
\text { LCOE }=\frac{\text { Total Lifetime costs }(\text { LKR) }}{\text { Total Lifetime Energy Output (kWh) }}
$$

The costs and benefits of the two types of plants were estimated as detailed below.

\subsection{Loan Details}

Financing for the UKHP was provided by Japan International Cooperation Agency (JICA) and the details are shown in Table 9.

Table 9 - Loan details of Talawakele ROR project

\begin{tabular}{|l|r|}
\hline \multicolumn{1}{|c|}{ Parameter } & \multicolumn{1}{|c|}{ Loan Details } \\
\hline Donor & $\begin{array}{r}\text { Japan International } \\
\text { Cooperation Agency (JICA) }\end{array}$ \\
\hline Agreement & 10 years \\
\hline Grace period & 30 years \\
\hline $\begin{array}{l}\text { Loan repayment } \\
\text { period }\end{array}$ & $0.93 \%$ on Japanese Yen (JPY) \\
\hline $\begin{array}{l}\text { Average interest } \\
\text { rate }\end{array}$ & $10.65 \%$ on Sri Lankan Rupees \\
\hline $\begin{array}{l}\text { Adjusted } \\
\text { interest rate }\end{array}$ & \\
\hline
\end{tabular}

\subsection{Project Cost and Loan Amount}

The project cost and the loan amount of the implemented Talawakele ROR project were calculated from the annual cost distribution data during the construction period. The result summary is given in Table 10.
Table 10 - Project cost and loan amount of Talawakele ROR project

\begin{tabular}{|l|r|}
\hline \multicolumn{1}{|c|}{ Parameter } & Value \\
\hline $\begin{array}{l}\text { Project cost (base year 2014) } \\
\text { (million LKR) }\end{array}$ & 53,040 \\
\hline $\begin{array}{l}\text { Original loan amount } \\
\text { (million LKR) }\end{array}$ & 47,251 \\
\hline $\begin{array}{l}\text { Loan as a percentage from project } \\
\text { cost (\%) }\end{array}$ & 89.00 \\
\hline $\begin{array}{l}\text { Adjusted loan amount at the end of } \\
\text { grace period (million LKR) }\end{array}$ & 51,834 \\
\hline
\end{tabular}

The project cost of Caledonia reservoir was taken from the Feasibility Study report [1]. The percentage of the original loan amount from the project cost was estimated as $89.00 \%$ to maintain the same conditions in both projects for comparison. The project cost summary for the Caledonia reservoir case is given in Table 11.

Table 11 - Project cost and loan amount of Caledonia reservoir project

\begin{tabular}{|l|c|}
\hline \multicolumn{1}{|c|}{ Parameter } & Value \\
\hline $\begin{array}{l}\text { Project cost (base year 1986) } \\
\text { (million LKR) }\end{array}$ & 7,920 \\
\hline $\begin{array}{l}\text { Adjusted project cost in 2014 } \\
\text { (million LKR) }\end{array}$ & 116,860 \\
\hline $\begin{array}{l}\text { Original loan amount } \\
\text { (million LKR) }\end{array}$ & 104,005 \\
\hline $\begin{array}{l}\text { Adjusted loan amount at the end of } \\
\text { grace period (million LKR) }\end{array}$ & 114,092 \\
\hline
\end{tabular}

For this study, loan repayment schedules of Talawakele ROR and Caledonia reservoir projects were considered during the 30 years of loan repayment period. The purpose was to obtain the cash outflow from capital repayments and interest payments (finance cost) in order to use for LCOE calculations.

\subsection{Plant Operation and Maintenance Cost}

Actual O\&M costs of the implemented Talawakele ROR type hydropower plant were obtained for year 2014, 2015 and 2016. The plant was commissioned on 14th July 2012 [25] and the O\&M cost could be exactly obtained since 2014. Those annual O\&M costs are given in Table 12.

Table 12 - O\&M cost of Talawakele ROR type hydropower plant

\begin{tabular}{|c|r|}
\hline Year & \multicolumn{2}{|c|}{$\begin{array}{c}\text { O\&M Cost } \\
\text { (million LKR) }\end{array}$} \\
\hline 2014 & 114.00 \\
\hline 2015 & 140.00 \\
\hline 2016 & 160.00 \\
\hline
\end{tabular}


These costs were extrapolated to obtain the O\&M costs for the rest of lifetime.

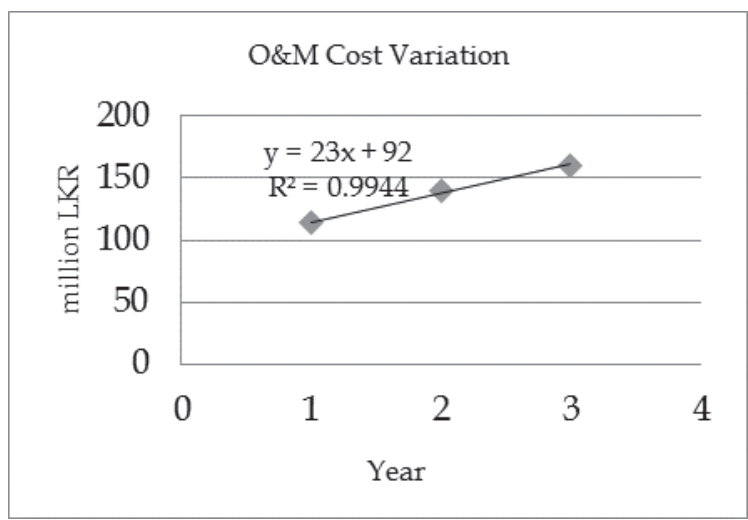

Figure 2 - O\&M cost variation of Talawakele ROR type hydropower plant

O\&M costs of Caledonia reservoir type hydropower plant were assumed to be proportionate to the plant capacity and hence the calculation of those were based on the O\&M costs of Talawakele ROR type hydropower plant. A sample calculation is given below.

O\&M cost of Caledonia reservoir plant in 2014 $($ million LKR $)=\underline{(23 \times 1+92)} \times 214 \mathrm{MW}$

$$
=164
$$

\subsection{Carbon Trading}

Carbon trading, which is also called Clean Development Mechanism (CDM), is an international market introduced by the Kyoto Protocol (KP) as a global strategy to combat global warming [26].

In this study, the average carbon trading price from August 2005 to November 2017 was calculated as Euro11.87/ton $\mathrm{CO}_{2}$. Average Euro to LKR exchange rate for the same period was calculated based on the CBSL data (1 Euro = 155.48 LKR). The converted average carbon trading price of $1,845.58 \mathrm{LKR} /$ ton $\mathrm{CO}_{2}$ was taken for the calculations in this study.

If UKHP was implemented under CDM, the GHG emission reduction compared to baseline emissions defined for CDM projects, could have been sold via carbon trading to earn an income. In this study, that was considered as benefits for both projects.

Grid Emission Factor (GEF) is a parameter to determine the baseline emissions for CDM projects in the renewable energy sector and waste heat/gas recovery sector. It refers to $\mathrm{CO}_{2}$ emission factor associated with each unit of electricity provided by an electricity system
[27]. The last updated GEF (in 2016) of Sri Lanka was taken for the calculations in this study.

GEF in Sri Lanka= 0.8199 ton $\mathrm{CO}_{2} / \mathrm{MWh}$ [28]

GHG emission reduction from Caledonia reservoir project compared to CDM baseline emissions

$$
\begin{aligned}
& =\left(0.8199 \times 664 \times 10^{3}-27,677.93\right) \text { ton } \mathrm{CO}_{2} / \text { year } \\
& =516,736 \text { ton } \mathrm{CO}_{2} / \text { year }
\end{aligned}
$$

Hence, CDM benefit (million LKR/year)= $(\mathrm{LKR} 1,845.58 /$ tonCO 2$) \times 516,736$ ton $\mathrm{CO}_{2} /$ year $=954$

GHG emission reduction from Talawakele ROR project compared to CDM baseline emissions $=\left(0.8199 \times 409 \times 10^{3}-7,553.37\right)$ ton $\mathrm{CO}_{2} /$ year $=327,786$ ton $\mathrm{CO}_{2} /$ year

Hence, CDM benefit (million LKR/year) $=\left(\right.$ LKR $1,845.58 /$ tonCO $\left._{2}\right) \times 327,786$ ton $\mathrm{CO}_{2}$ /year $=605$

\subsection{Levelized Cost of Electricity Calculation and Economic Comparison}

With above costs and benefits, two cash flows were prepared and Net Present Value (NPV) of total costs and NPV of energy were calculated considering the lifetime of the plants. The results are given in Table 13.

Table 13 - LCOE calculation summary

\begin{tabular}{|l|r|r|}
\hline \multicolumn{1}{|c|}{ Parameter } & $\begin{array}{c}\text { Caledonia } \\
\text { Reservoir } \\
\text { Project }\end{array}$ & $\begin{array}{c}\text { Talwakele } \\
\text { ROR } \\
\text { Project }\end{array}$ \\
\hline $\begin{array}{l}\text { NPV (Costs) } \\
\text { MLKR }\end{array}$ & 101,242 & 45,300 \\
\hline $\begin{array}{l}\text { NPV (Energy) } \\
\text { GWh }\end{array}$ & $6,583.44$ & $4,055.16$ \\
\hline $\begin{array}{l}\text { LCOE } \\
(\text { LKR/kWh) }\end{array}$ & $\mathbf{1 5 . 3 8}$ & $\mathbf{1 1 . 1 7}$ \\
\hline
\end{tabular}

From Table 13, it can be seen that the LCOE from Talawakele ROR project is substantially lower compared to the Caledonia reservoir type project.

\section{National Benefit}

Reservoirs can store water and hence the expected operation during peak demand hours can be obtained in both dry seasons and wet seasons of a year. In ROR, the flowing water is collected and stored during the day time in dry seasons in order to operate during the night peak. The expected peak operation may not always be possible because the stored water 
amount may not be sufficient to cover the entire peak period which is from 18.30 hours to 22.30 hours in Sri Lanka.

National benefits due to night peak operation of Caledonia reservoir and Talawakele ROR hydropower plants were calculated as detailed below.

$$
\begin{array}{lll}
\text { Installed capacity } & =214 \\
\text { Annual energy }(\mathrm{GWh}) & =664 \\
\mathrm{LCOE}(\mathrm{LKR} / \mathrm{kWh}) & =15.38 \\
\text { Night peak hours per day } & =4 \\
\text { Annual night peak generation }(\mathrm{GWh}) & =214 \times 4 \times 365 \times 90 \% \times 10^{-3} \\
= & 281.20
\end{array}
$$

Annual cost of generation during night peak $($ million LKR) $\quad=281.20 \times 15.38$

$$
=4,325
$$

Similarly, calculations were made for Talawakele ROR hydropower plant. Accordingly,

Annual night peak generation (GWh)

$$
=197.10
$$

Annual cost of generation during night peak (million LKR)

$$
\begin{aligned}
& =197.10 \times 11.17 \\
& =2,202
\end{aligned}
$$

Case 1: assuming rated operation of UKHP during the total night peak period of a year,

Annual financial loss or negative national benefit due to not having the Caledonia reservoir plant (million LKR)

$$
=4,325-2,202=2,123
$$

According to the results shown in Case 1, even though the Talwakele ROR hydropower plant operates in its full capacity (assuming every year is a wet year), there is an annual loss of LKR 2,123 million to the country by not having the Caledonia reservoir plant for peak serving.

Case 2: based on the actual night peak operation data of UKHP obtained from System Control Centre (SCC) of Ceylon Electricity Board (CEB), annual financial loss,

Table 14 - night peak generation of UKHP on actual basis and financial loss or negative national benefit by not having Caledonia reservoir plant

\begin{tabular}{|c|r|r|r|}
\hline Year & $\begin{array}{c}\text { Night Peak } \\
\text { Generation } \\
\text { (GWh) }\end{array}$ & $\begin{array}{c}\text { Annual Cost } \\
\text { of Night Peak } \\
\text { Generation } \\
\text { (million LKR) }\end{array}$ & $\begin{array}{c}\text { Annual } \\
\text { Financial } \\
\text { Loss } \\
\text { (million } \\
\text { LKR) }\end{array}$ \\
\hline 2014 & 172.00 & 1921 & 2,404 \\
\hline 2015 & 187.00 & 2089 & 2,236 \\
\hline 2016 & 146.00 & 1631 & 2,694 \\
\hline
\end{tabular}

SCC daily records the maximum output (MW) of UKHP during the night peak operation and the time it occurred. In this study, it was assumed that the plant operated with that output for the total night peak period in the respective days. Accordingly, the generated night peak energy were calculated for each year from 2014 to 2016 as shown in Table 14.

The results of Case 1 and Case 2 are summarized and given in Table 15.

Table 15 - Annual financial loss or negative national benefit based on rated and actual operation of Talawakele ROR project

\begin{tabular}{|l|r|r|}
\hline Year & \multicolumn{1}{|c|}{$\begin{array}{c}\text { Case 1: } \\
\text { Loss } \\
\text { (million LKR) }\end{array}$} & $\begin{array}{c}\text { Case 2: } \\
\text { Loss } \\
\text { (million LKR) }\end{array}$ \\
\hline 2014 & 2,123 & 2,404 \\
\hline 2015 & 2,123 & 2,236 \\
\hline 2016 & 2,123 & 2,694 \\
\hline
\end{tabular}

\section{Conclusions and \\ Recommendations}

It is concluded that GHG emission considerations are not strong enough to discourage reservoir type new hydropower plant developments.

According to the LCOE results, it can be concluded that the ROR type has the overall economic benefit in the case of UKHP, but if the project objective is solely to capture the maximum hydropower potential or peak serving, it can be concluded that the reservoir type has a better overall economic benefit to the country.

It is recommended that for similar future large hydropower developments, a detailed similar study to be carried out before taking the decision on reservoir construction for hydropower generation. A case by case study is recommended to be conducted because the environmental factors such as the impact of flooding, melting snow and ice, etc. vary from location to location. The methodology presented in this study can be followed for such studies with suitable modifications where necessary.

Although hydropower projects do not have
zero GHG emissions, as per this study, they
are much less compared to thermal power
plants. In view of grave need for limiting the
average global temperature increase to $2^{\circ} \mathrm{C}$ by
the end of this century and the GHG emission
reduction commitments made at the COP 21 at 
Paris, it is recommended that as many largescale hydropower projects as possible to be implemented capturing all possible hydropower potential in the world.

\section{Acknowledgement}

Authors wish to acknowledge the assistance given by the Project Director of UKHP to obtain data related to the existing Talawakele run of the river type hydropower project. At the same time, authors wish to acknowledge the Chief Engineer of Generation Planning Unit of Ceylon Electricity Board for giving access to obtain data related to the previously planned Caledonia reservoir type hydropower project. Authors also wish to acknowledge the assistance given by Deputy General Manager of the System Control Centre of Ceylon Electricity Board to obtain the past night peak operational data of UKHP. Finally, authors wish to acknowledge the Chief Engineer of UKHP for providing the actual operation and maintenance cost data of the existing UKHP.

\section{References}

1. Schaeffer, R. et al., "The vulnerable amazon: the impact of climate change on the untapped potential of hydropower systems," IEEE Power. Energy. Mag., vol. 11, no. 3, pp. 22-31, Apr. 2013.

2. Harrison, G. P. and Whittington, H. W., "Vulnerability of Hydropower Projects to Climate Change," Proc. IEE - Gener. Transm. Distrib., vol. 149, no. 3, pp. 249-255, May 2002.

3. Hennig, T. et al., "Review of Yunnan's Hydropower Development. Comparing small and large Hydropower Projects Regarding their Environmental Implications and Socio-economic Consequences," Renewable and Sustainable Energy Reviews, vol. 27, pp. 585-595, Nov. 2013.

4. Zhang J. et al., "Review on the Externalities of Hydropower: A Comparison between Large and Small Hydropower Projects in Tibet based on the $\mathrm{CO}_{2}$ Equivalent," Renewable and Sustainable Energy Reviews, vol. 50, pp. 176-185, Oct. 2013.

5. Kumar, D. and Katoch, S. S., "Environmental Sustainability of Run of the River Hydropower Projects: A Study from Western Himalayan Region of India," Renewable Energy, vol. 93, pp. 599-607, Aug. 2016.

6. Morimoto, R., "Incorporating SocioEnvironmental Considerations into Project Assessment Models using Multi-Criteria Analysis: A Case Study of Sri Lankan Hydropower Projects," Energy Policy, vol. 59, pp. 643-653, Aug. 2013.
7. Yang, L. et al., "Progress in the Studies on the Greenhouse Gas Emissions from Reservoirs," Acta Ecologica Sinica, vol. 34, no.4, pp. 204-212, Aug. 2014.

8. Hidrovo, A. B. et al., "Accounting for GHG net Reservoir Emissions of Hydropower in Ecuador," Renewable Energy, vol. 112, pp. 209221, Nov. 2017.

9. Descloux, S. et al., "Methane and Nitrous Oxide Annual Emissions from an Old Eutrophic Temperate Reservoir," Science of The Total Environment, vol. 598, pp. 959-972, Nov.2017.

10. Santos, M. A. D. et al., "Estimation of GHG Emissions by Hydroelectric Reservoirs: The Brazilian Case," Energy, vol.133, pp. 99-107, Aug. 2017.

11. Demarty, M. and Bastien, J., "GHG Emissions from Hydroelectric Reservoirs in Tropical and Equatorial Regions: Review of 20 years of $\mathrm{CH}_{4}$ Emission Measurements," vol.39, pp. 4197-4206, Jul. 2011.

12. Demlas, R., and Lacaux, C. G., "Emissions of Greenhouse Gases from the Tropical Hydroelectric Reservoir of Petit Saut (French Guiana) Compared with Emissions from Thermal Alternatives," Global biogeochemical Cycles, vol.15, no.4, pp. 993-1003, Dec. 2001.

13. Santos, M. A. D. et al., "Gross greenhouse gas fluxes from hydro-power reservoir compared to thermo-power plants," Energy Policy, vol.34, no.4, pp. 481-488, Mar. 2006.

14. [Online]. Available: https://www.ceb.lk/power-plants-list/en.

15. Japan International Corporation Agency, "Feasibility Study on Upper Kotmale Hydroelectric Power Development Project," Ceylon Electricity Board, Sri Lanka, Final Rep., Aug. 1987.

16. Guo, Z. et al., "Ecosystem Functions, services and their values - a case study in Xingshan County of China," Ecological Economics, vol. 38, no. 1, pp. 141-154, Jul. 2001.

17. World Heritage Encyclopedia. Primary Production[Online].Available:

http://www.ebooklibrary.org/Articles/Prim ary $\% 20$ production?\&Words=primary $\% 20$ pro duction.

18. Zhang, J. et al., "Review on the Externalities of Hydropower: A Comparison between Large and Small Hydropower Projects in Tibet based on the $\mathrm{CO}_{2}$ equivalent," Renewable and Sustainable Energy Reviews, vol. 50, pp. 176185, Oct. 2013. 
19. Demarty, M., and Bastien, J. "GHG Emissions from Hydroelectric Reservoirs in Tropical and Equatorial Regions: Review of 20 years of $\mathrm{CH}_{4}$ Emission Measurements," vol.39, pp. 4197-4206, Jul. 2011.

20. Demlas, R. and Lacaux, C. G. "Emissions of Greenhouse Gases from the Tropical Hydroelectric Reservoir of Petit Saut (French Guiana) Compared with Emissions from Thermal Alternatives," Global biogeochemical Cycles, vol.15, no.4, pp. 993-1003, Dec. 2001.

21. [Online]. Available:

https://definedterm.com/boreal_region.

22. Turconi, R. et al., "Life Cycle Assessment (LCA) of Electricity Generation Technologies: Overview, Comparability and Limitations," Renewable and Sustainable Energy Reviews, vol. 28, pp. 555-565, Dec. 2013.

23. Zhang, S. et al., "Carbon Footprint Analysis of two Different Types of Hydropower Schemes: Comparing Earth-Rockfill Dams and Concrete Gravity Dams using Hybrid Life Cycle Assessment," vol. 103, pp. 854-862, Sep. 2015.

24. Hondo, S. "Life Cycle GHG Emission Analysis of Power Generation Systems: Japanese Case," Energy, vol. 30, no. 11-12, pp. 2042-2056, Aug-Sep. 2005.

25. Ceylon Electricity Board. (2004). Upper Kotmale Hydropower Project [Online]. Available: http://www.ukhp.lk.

26. Batagoda, B. M. S., “Carbon Trading: A New International Business Opportunity in Sri Lanka," Economic Review, pp. 41-62, Jun/Jul. 2008.

27. Rocamora, A. and Amellina, A. (2017, November). IGES List of Grid Emission Factors [Online].Available:https://pub.iges.or.jp/pub /iges-list-grid-emission-factors.

28. [Online]. Available:

http://energybalance.axioon.com/. 